\title{
Solar thermal and electricity. A state of the art
}

\section{Energía solar térmica y electricidad. Un estado del arte}

\author{
Debrayan Bravo Hidalgo ${ }^{\mathrm{a}}$ \\ Alexander Báez Hernández
}

Fecha de Recepción: 25.03.2020

Fecha de Aceptación: 17.05.2020

Doi: https://doi.org/10.19053/01217488.v11.n2.2020.10656

\begin{abstract}
The objective of this contribution is to provide a state-of-the-art on research in solar thermal electricity systems. This objective is achieved using Scopus, and the softwears "Publish or Perish" and "VOSviewer". The results of the research show the behavior of scientific productivity in this area. As well as the most productive thematic areas. Nations that lead the research in the generation of electric power on a large scale, using solar thermal energy. Network of scientific collaboration among nations, referring to the research of electricity generation through solar thermal energy. Correlation network among the most productive authors, in this subject within the Scopus directory. Most cited articles by each of the main journals that disseminate this theme. Conceptual bases of the generation of electricity with solar thermal energy. Properties of thermal energy storage technologies (TES) in power plants with parabolic solar concentrators or solar concentration towers. Current technologies and trends. Technological trends. Trends in the global energy market.
\end{abstract}

Keywords: electricity generation, solar thermal energy, thermal energy storage, energy market trends, text mining.

\section{Resumen}

El objetivo de esta contribución es proporcionar un estado del arte de las investigaciones en sistemas de energía solar térmica para la generación de electricidad. Este objetivo se logra utilizando Scopus y los softwears "Publish or Peish" y "VOSviewer". Los resultados de la investigación muestran el comportamiento de la productividad científica en esta área. Así como las áreas temáticas más productivas. Naciones que lideran la investigación en la generación de energía eléctrica a gran escala, utilizando energía solar térmica. Red de colaboración científica entre naciones, referida a la investigación de generación eléctrica a través de energía solar térmica. Red de correlación entre los autores más productivos, en este tema dentro del directorio Scopus. Artículos más citados por cada una de las principales revistas que difunden este tema. Bases conceptuales de la generación de electricidad con energía solar térmica. Propiedades de las tecnologías de almacenamiento de energía térmica (TES) en plantas de energía con concentradores solares parabólicos o torres de concentración solar. Tendencias tecnológicas. Tendencias en el mercado energético mundial.

Palabras clave: generación de electricidad, energía solar térmica, almacenamiento de energía térmica, tendencias del mercado energético, minería de texto.

\footnotetext{
Universidad San Francisco de Quito, (USFQ) Ecuador, dbrayanbh@gmail.com

b Universidad Central del Ecuador, (UCE), Ecuador, albaez@uce.edu.ec
} 


\section{INTRODUCTION}

The electrical energy generated from solar thermal energy can be defined as the result of a process through which the collected solar energy is converted into electricity through the use of some type of device for converting heat into electricity [1-3]. It is mostly a thermal engine, but there are other options, such as solar chimneys with pneumatic turbines $[4,5]$. Solar thermal electricity did not find its presence in electro-energy networks until the 1980s, although the basic technology for the production of mechanical energy that could be converted to electricity with a conventional generator was available for several decades [6]. The period of the eighties saw the birth of the first thermo-solar installations in order to produce electricity on a large scale [7]. This fact was a response to the challenges of the oil crisis of the $70 \mathrm{~s}$. These conditions promoted the improvement and optimization of the most diverse elements of solar capture $[8,9]$.

Solar thermal energy probably has the greatest potential of any other source of renewable energy in the tropics [10], but its development has been delayed due to the resistance of the energy market to large plants and the poor political and financial support of programs of incentives. However, at this time there is rapid development in both basic technology and market strategy, and the prospects for rapid growth now seem to be very clear in the global energy context [11, 12].

The research problem dealt with in this document is the representation of the most established technologies in the generation of electrical energy in solar thermal installations, and the technological and market trends of this ecological energy proposal. In this document you can find information such as: (i) Unestudios bibliometroc que destaca, entre otras informaciones, los artículos más citados por cada una de las principales revistas que difunden resultados de investigaciones en Solar thermal electricity. (ii) Bases conceptuales de la generación de electricidad con energía solar térmica. (iii)Most innovative contributions, for each of the techniques for generating electricity through solar thermal energy. (iv)Properties of thermal energy storage technologies (TES) in power plants with parabolic solar concentrators or solar concentration towers. Current technologies and trends. (v)Trends in the global energy market.

\section{MATERIALS AND METHODS}

For the selection and study of the information that allowed the development of this research, the academic directory "Scopus", the "Publish or Perish" softwear and the "VOSviewer (POP)" softwear were used.

Scopus is a bibliographic database of abstracts and citations of scientific articles and journals. This directory covers approximately 18,000 titles from more than 5,000 publishers worldwide, covering 17,000 peer-reviewed journals in the areas of science, technology, social sciences, among others [13]. The Scopus directory, and the information analysis accessories that it provides to its subscribers, allowed the analysis of the performance of the research related to the generation of electricity from solar thermal energy. The "Solar Thermal Electricity" frace was used as a search criterion in the title, abstract and keywords of the research published in Scopus. With the bibliometric analysis tools provided by Scopus, figures 1, 3, 4 and 7 were made.

Publish or Perish is a software program that retrieves and analyzes academic citations. It uses a variety of data sources (incl. Google Scholar and Microsoft Academic Search) to obtain the raw citations, then analyzes these and presents the following metrics: Total number of papers and total number of citations, average citations per paper, citations per author, papers per author, and citations per year, Hirsch's h-index [14] and related parameters, and others. Through this program, the $\mathrm{H}$ index of the investigations referred to in tables 1 and 2 was determined.

VOSviewer is a software tool for constructing and visualizing bibliometric networks. These networks may for instance include journals, researchers, or individual publications, and they can be constructed based on citation, bibliographic coupling, co-citation, or co-authorship relations. VOSviewer also offers text mining functionality that can be used to construct and visualize cooccurrence networks of important terms extracted from a body of scientific literature.

From Scopus, the data was imported in CSV format; and it was processed in the VOSviewer software. The information of the detected contributions contained: (i) Title. (ii) Keywords. (iii) Author. (iv) Year of publication. (v) Institution of the authors. (vi) Nationality. (vii) citation index. 
VOSviewer was used in text mining and to analyze data from bibliometric networks, collaborative relationships between nations and authors. In addition, it was used to obtain the relation of coincidence between scientific terms under the search criteria previously exposed. With this software figure 2, 5 and 6 were made.

\section{RESULTS}

From 1960 to the present time, 4,154 articles and 54,922 patents related to the topic dealt with in this work are registered in the Scopus database. Figure 1 shows how the number of publications is distributed. There is a growing interest for scientists and engineers in the electric generation with solar thermal energy in the first five years of this century. Trend that has been increasing [15-18].

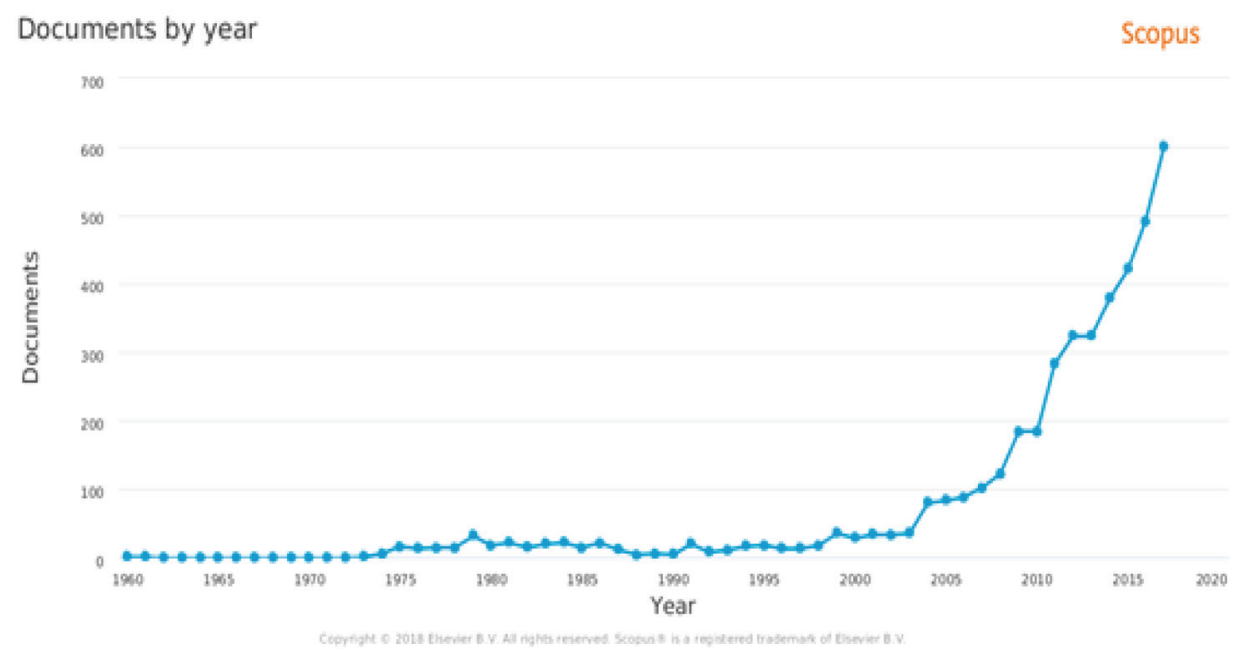

Figure 1. Number of publications or contributions in recent decades. TITLE-ABS-KEY (solar AND thermal AND electricity).

Figure 2 shows a map of scientific terms related to research in the area of electricity generation from solar thermal energy. In this map of terms, the density of the co-occurrence of the term in the contributions is given by the range of colors. Where the red color represents greater density, and its degradation to blue represents less co-occurrence of the term or density of this.

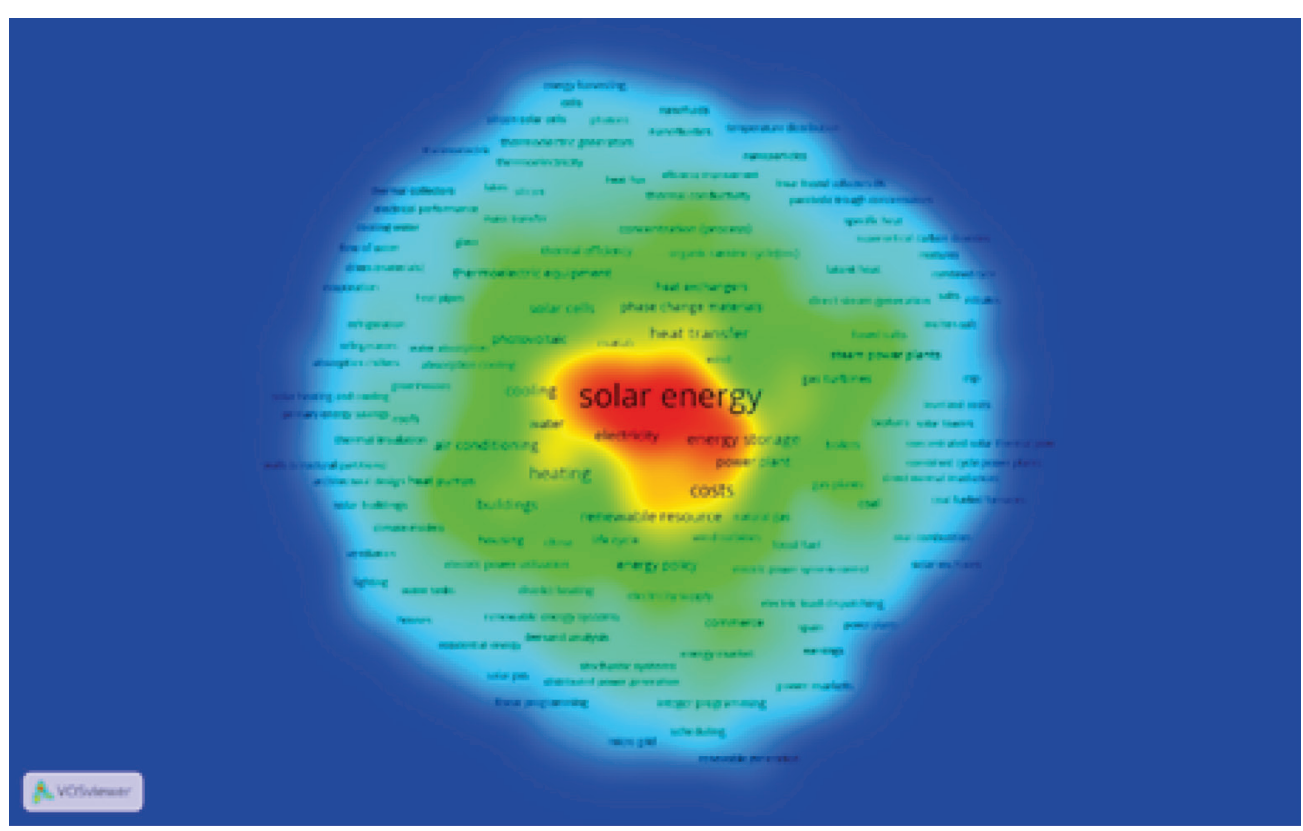

Figure 2. Map of density of terms. 
Figure 3 shows how the scientific contributions detected by the different research areas are distributed. Research in energy and engineering are the most proliferating.

Documents by subject area

Scopus

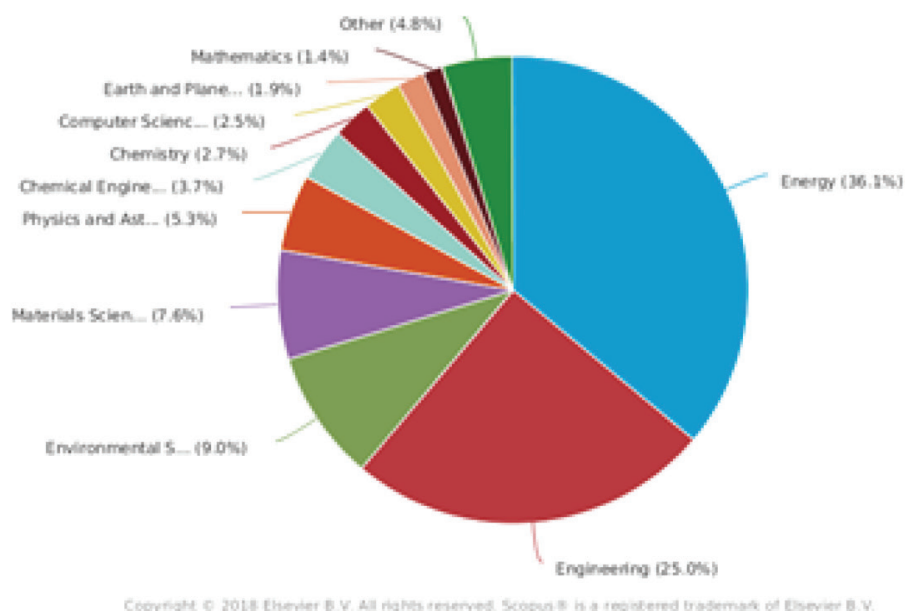

Figure 3. Percentage value of contributions for the different research areas detected in Scopus. TITLE-ABS-KEY (solar AND thermal AND electricity).

The great economic powers worldwide see in the thermo solar generation a financially viable alternative and ecology, in the face of the adversities that the energy market currently presents. This can be corroborated in the information shown in figure 4 .

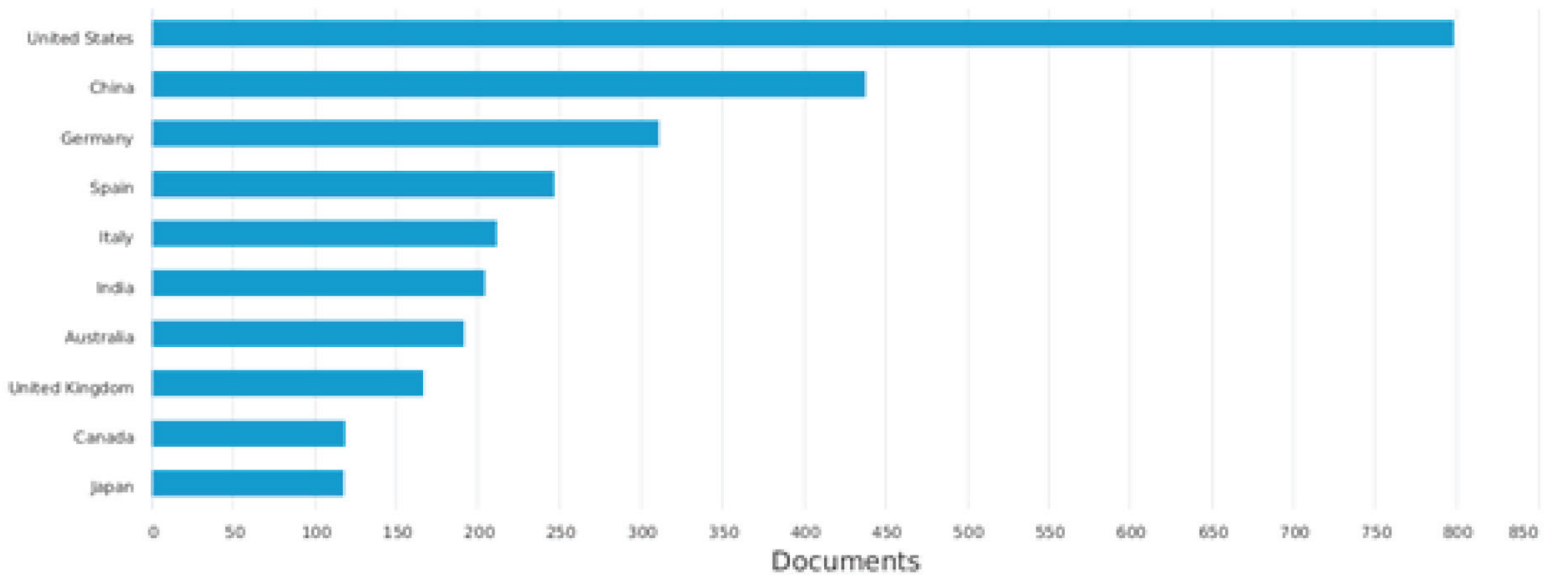

Figure 4. Nations that lead the research in the generation of electric power on a large scale, using solar thermal energy. TITLE-ABS-KEY (solar AND thermal AND electricity)

Figure 5 shows how you relate to the aforementioned nations, in terms of research collaborations and scientific productivity. It is evident that the current economic powers emerge as the epicenter of international scientific collaborations in this field. 


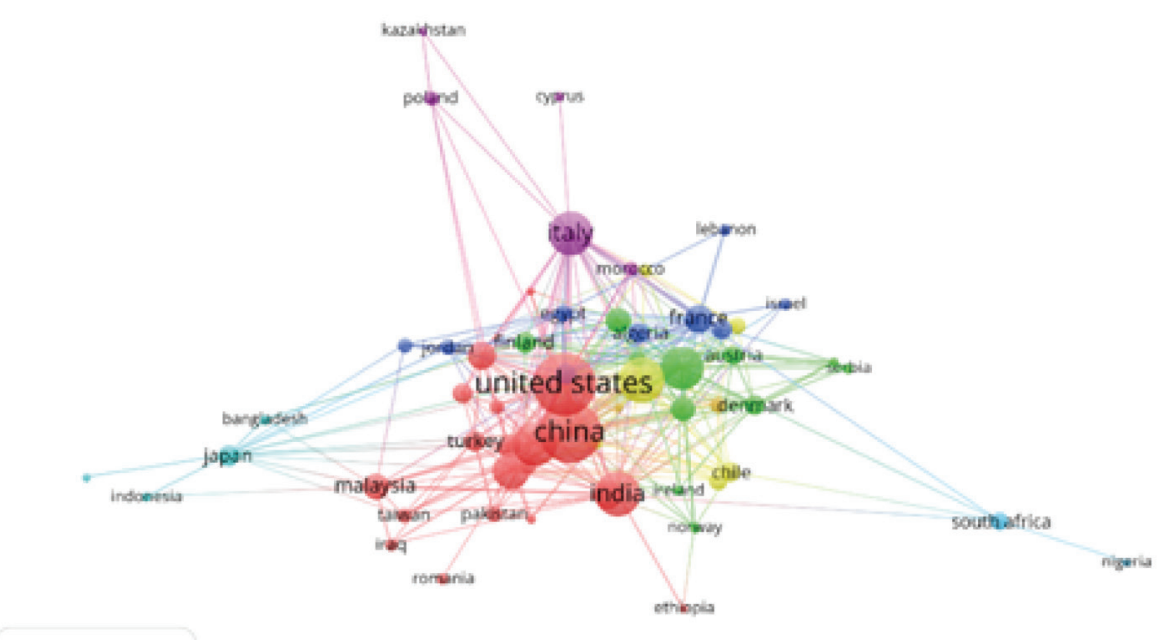

1. vosviewer

Figure 5. Network of scientific collaboration among nations, referring to the research of electricity generation through solar thermal energy.

The author of greater productivity globally is a member of the Institute of Engineering Thermophysics Chinese Academy of Sciences, Beijing, China. His name is Hongguang Jin, and he has 32 scientific contributions in the academic research catalog Scopus. Said catalog records 3313 citations of the researches of this author. Figure 6 shows the co-authorship network among the most productive authors of the last three years. The range of colors of this graphic allows to locate the researchers in the period of time. The size of the boxes named, establishes the intensity of the scientific production of each author. In the graph you can see that there is a strong correlation between these authors, which justifies that the sizing of these tables is very balanced.

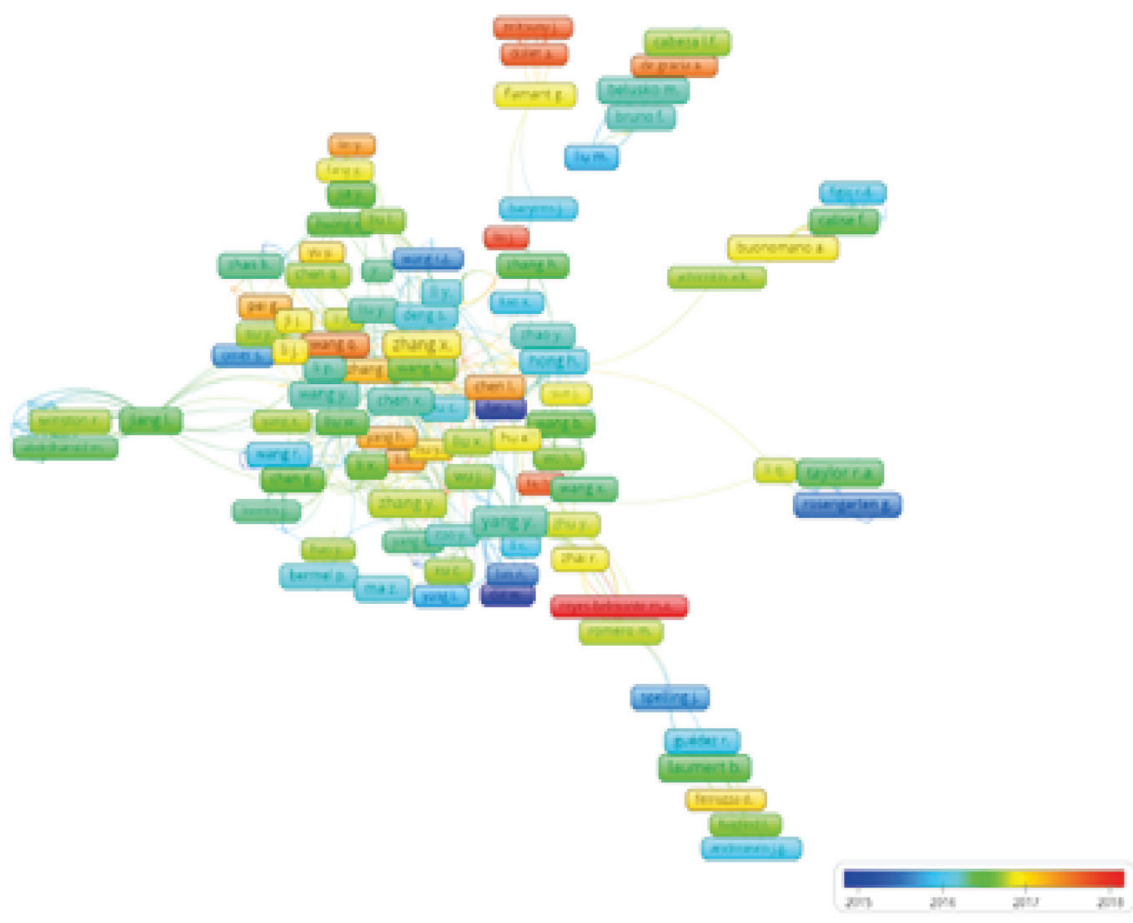

Figure 6. Correlation network among the most productive authors, in this subject within the Scopus directory. 
The journals that offer the greatest visibility to research in the area of electricity generation from solar thermal energy are: Energy Proceia, Solar
Energy, Renewable Energy, Energy, and Applied Energy. See figure 7.

Documents per year by source

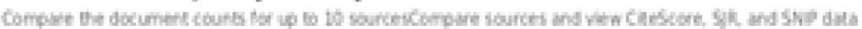

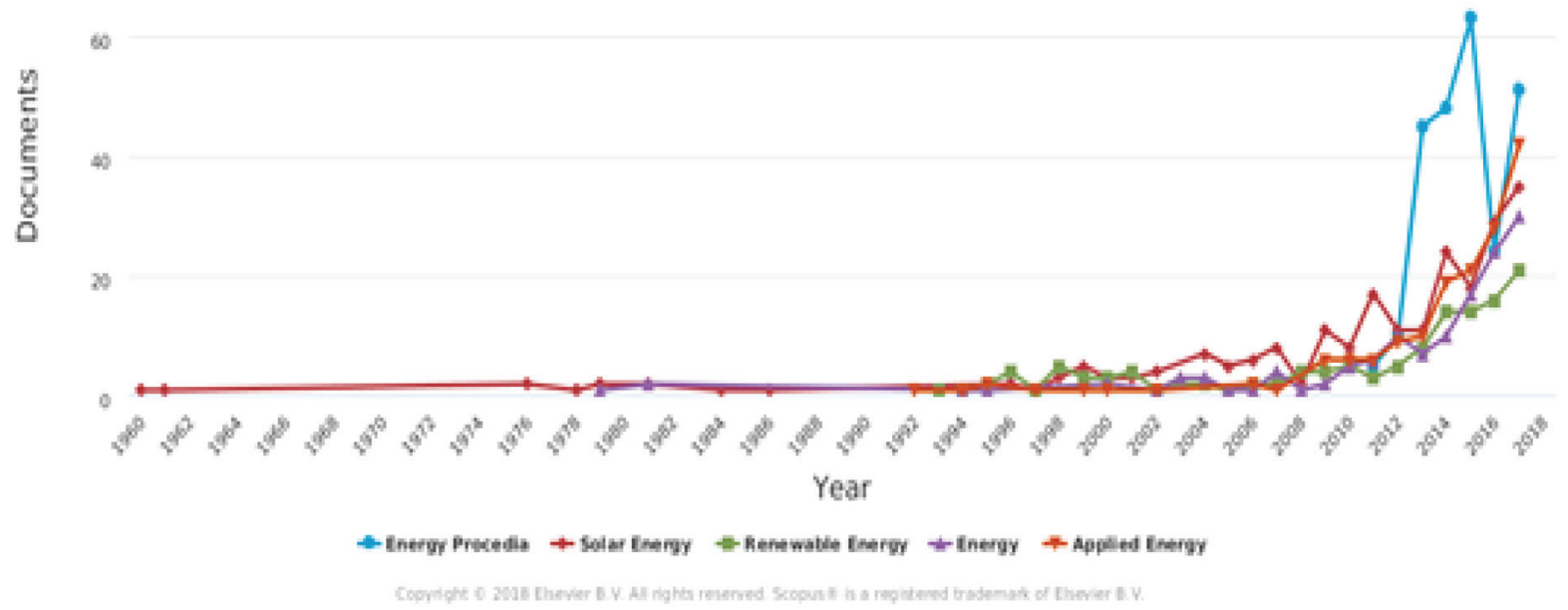

Figure 7. Journals that offer greater socialization worldwide, to the topic addressed. TITLE-ABS-KEY (solar AND thermal AND electricity).

Table 1 shows the contributions most referenced or cited by the international scientific community; for each of the magazine shown in Figure 7. The Hirsch index (h) of each investigation is expressed in the last column of this table. The $\mathrm{h}$ index was detected using Publish or Perish software. This tool allowed defining the projection in terms of citations, of each of these articles, not only within the Scopus academic directory, but also in Google Scholar, Science Direct and the Web of Science.

The main result evidenced by this table is that research in thermal accumulation systems represents a fundamental part in the process of optimization and economic competitiveness of electric power generation systems based on solar thermal energy [19]. 


\begin{tabular}{|c|c|c|c|c|c|c|c|}
\hline Source title & Article title & Authors & Abstract & Keywords & Year & $\begin{array}{l}\text { Index H } \\
\text { detected }\end{array}$ & $\begin{array}{l}\text { Refe- } \\
\text { rence }\end{array}$ \\
\hline $\begin{array}{l}\text { Energy } \\
\text { Procedia }\end{array}$ & $\begin{array}{l}\text { A high-efficien- } \\
\text { cy solar thermal } \\
\text { power plant } \\
\text { using a dense } \\
\text { particle suspen- } \\
\text { sion as the heat } \\
\text { transfer fluid }\end{array}$ & $\begin{array}{l}\text { J. Spelling, A. } \\
\text { Gallo, M. } \\
\text { Romero, J. } \\
\text { González Aguilar }\end{array}$ & $\begin{array}{l}\text { A novel solar power plant concept is presented, based on the } \\
\text { use of a dense particle suspension as the heat transfer fluid } \\
\text { which allows receiver operation at high temperatures (above } \\
650^{\circ} \mathrm{C} \text { ), opening the possibility of using high-efficiency pow- } \\
\text { er generation cycles such as supercritical Rankine cycles. A } \\
50 \text { MWe solar power plant was designed based on this new } \\
\text { heat transfer fluid and compared with a conventional molten } \\
\text { salt solar power plant. The supercritical Rankine-cycle power } \\
\text { block increases the termal conversion efficiency from } 39.9 \% \\
\text { to } 45.4 \% \text {, corresponding to a } 9.6 \% \text { reduction in the size of the } \\
\text { heliostat field. The operating temperature range is increased by } \\
24.5 \% \text {, which leads to a } 12.5 \% \text { increase in storage density and } \\
\text { a } 22.5 \% \text { reduction in the total storage volume. Parasitic power } \\
\text { consumption is also reduced due to the elimination of the need } \\
\text { for heat tracing. Overall, the combination of increased cycle } \\
\text { efficiency, increased storage density and reduced parasitics to } \\
\text { leads to a predicted electricity cost reduction of } 10.8 \%\end{array}$ & $\begin{array}{l}\text { Dense particle } \\
\text { suspensión, } \\
\text { supercritical steam- } \\
\text { cycle, high efficiency } \\
\text { solar power }\end{array}$ & 2015 & 28 & [20] \\
\hline $\begin{array}{l}\text { Solar } \\
\text { Energy }\end{array}$ & $\begin{array}{l}\text { Analysis of } \\
\text { HTFs, PCMs } \\
\text { and fins effects } \\
\text { on the thermal } \\
\text { performance } \\
\text { of shell-tube } \\
\text { thermal energy } \\
\text { storage units }\end{array}$ & $\begin{array}{l}\text { Zhuo Li, Zhi-Gen } \\
\text { Wu }\end{array}$ & $\begin{array}{l}\text { In solar thermal power plant, the thermal energy storage (TES) } \\
\text { system is a key component which includes thermal energy } \\
\text { storage unit, thermal energy storage material and heat transfer } \\
\text { fluid (HTF). We numerically simulate the dynamical thermal } \\
\text { performances of shell-tube TES units with diverse geometric } \\
\text { configurations, phase change materials (PCMs) including pure } \\
\text { NaNO3 and a composite of NaNO3/expanded graphite (EG), } \\
\text { and HTFs such as synthetic oil and molten salts. In the charg- } \\
\text { ing/discharging process, the conjugated heat transfer behavior } \\
\text { between the thermal storage unit and thermal carriage chan- } \\
\text { nel is specially concerned. Effects of the extended fin, PCMs } \\
\text { and HTFs on improving heat. performance are examined } \\
\text { and quantified with total heat flux and effective Nus- } \\
\text { selt numbers. Together with the presented diagrams } \\
\text { of PCM phase evolution, the roles of heat conduc- } \\
\text { tion and natural convection in influencing the ther- } \\
\text { mal behavior of the TES units are clearly revealed. }\end{array}$ & $\begin{array}{l}\text { Thermal energy } \\
\text { storagePhase change } \\
\text { materialHeat transfer } \\
\text { fluidEnhancing heat } \\
\text { transfer }\end{array}$ & 2015 & 35 & [21] \\
\hline
\end{tabular}




\begin{tabular}{|c|c|c|c|c|c|c|c|}
\hline & & & $\begin{array}{l}\text { The nonuniform phase distribution of PCM due to natural } \\
\text { convection results in a considerable time spent in the end of } \\
\text { the charging/discharging processes. The results show that } \\
\text { both the full melting time and solidification time can be } \\
\text { shortened at least } 14 \% \text {, benefited from using the extended } \\
\text { fins and the composite. This study is expected to provide } \\
\text { an apprehensive interpretation of thermal transport mecha- } \\
\text { nism and rational advices in optimizing the TES system } \\
\text { operation. }\end{array}$ & & & & \\
\hline $\begin{array}{l}\text { Renewable } \\
\text { Energy }\end{array}$ & $\begin{array}{l}\text { Design and } \\
\text { feasibility } \\
\text { of high } \\
\text { temperature } \\
\text { shell and } \\
\text { tube latent } \\
\text { heat thermal } \\
\text { energy storage } \\
\text { system for solar } \\
\text { thermal power } \\
\text { plants }\end{array}$ & $\begin{array}{l}\text { S. Saeed } \\
\text { MostafaviTehrani, } \\
\text { Robert A. Taylor, } \\
\text { Pouya Saber, Gonzalo } \\
\text { Diarce }\end{array}$ & $\begin{array}{l}\text { A simple shell and tube heat exchanger provide a straight- } \\
\text { forward design for near-term integration of latent heat ther- } \\
\text { mal energy storage (LHTES) systems in concentrated solar } \\
\text { thermal-tower (CST-tower) plants, but currently there is no } \\
\text { literature available for this configuration in the } 286-565 \\
{ }^{\circ} \mathrm{C} \text { temperature range. Therefore, the primary objective of } \\
\text { this work is to evaluate the potential of this configuration } \\
\text { for CST-tower plants. In addition, a proper design method } \\
\text { of this storage configuration should simultaneously account } \\
\text { for the effects of geometric parameters and the number of } \\
\text { modules. The present work optimizes these parameters for } \\
\text { market ready phase change materials (PCM) that are suit- } \\
\text { able in the aforementioned temperature range. This optimi- } \\
\text { zation consisted of fixing the PCM volume while varying } \\
\text { the other geometric parameters (namely, L, L/d, R/ro) si- } \\
\text { multaneously over a wide range. The goal was to achieve } \\
\text { the highest amount of total stored/delivered energy with a } \\
\text { minimum heat transfer surface area. This analysis revealed } \\
\text { that there was an optimum area between } 36 \text { and } 63 \text { m } 2 \\
\text { GJ- } 1 \text { (or } 0.12-0.22 \text { m } 2 \mathrm{kWhth}-1 \text { ), depending on the PCM } \\
\text { employed. This optimum surface area can be obtained with } \\
\text { several combinations of geometric parameters, but only cer- } \\
\text { tain combinations were found to achieve the highest total } \\
\text { stored/delivered energy. The charging and discharging ef- } \\
\text { ficiency for the selected PCMs was found to be } ~ 99 \% \text { and } \\
75-85 \% \text {,respectively. Using the optimized designs, the cost } \\
\text { of this shell and tube LHTES system was found to vary be- } \\
\text { tween } 27 \text { and } 170 \text { US } \$ \text { kWhth- } 1 \text {, which indicates that with } \\
\text { further development it may be competitive with conven- } \\
\text { tional sensible storage systems (e.g. two-tank molten salts). }\end{array}$ & $\begin{array}{l}\text { High temperature } \\
\text { Phase change } \\
\text { material } \\
\text { Concentrating solar } \\
\text { power Parametric } \\
\text { analysis } \\
\text { Optimization } \\
\text { Shell and tube tank }\end{array}$ & 2017 & 25 & [22] \\
\hline
\end{tabular}




\begin{tabular}{|c|c|c|c|c|c|c|c|}
\hline Energy & $\begin{array}{l}\text { Optimization } \\
\text { of multiple } \\
\text { receivers solar } \\
\text { power tower } \\
\text { systems }\end{array}$ & $\begin{array}{l}\text { E. Carrizosa, C. } \\
\text { Domínguez- } \\
\text { Bravo, E. } \\
\text { Fernández-Cara, } \\
\text { M. Quero }\end{array}$ & $\begin{array}{l}\text { In this article a new procedure to optimize the design of a solar } \\
\text { power tower system with multiple receivers is presented. The } \\
\text { variables related to the receivers (height, aperture tilt angle, } \\
\text { azimuth angle and aperture size) as well as the heliostat field } \\
\text { layout are optimized seeking to minimize the levelized cost of } \\
\text { thermal energy. This is a high dimensional optimization prob- } \\
\text { lem with black-box nonconvex objective function. } \\
\text { The proposed strategy alternatively optimizes the receivers } \\
\text { and the heliostat field. A separate aiming region is considered } \\
\text { for each receiver. The aiming regions, the number of heliostats } \\
\text { and their locations are obtained with the proposed procedure. } \\
\text { Specifically, heliostat positions are obtained through a pattern- } \\
\text { free greedy-based location method. }\end{array}$ & $\begin{array}{l}\text { Solar thermal power, } \\
\text { Heliostat field lay- } \\
\text { out, Nonconvex } \\
\text { optimization, Greedy } \\
\text { algorithm, Multiple } \\
\text { receivers }\end{array}$ & 2015 & 14 & [23] \\
\hline $\begin{array}{l}\text { Applied } \\
\text { Energy }\end{array}$ & $\begin{array}{l}\text { Application of } \\
\text { phase change } \\
\text { materials for } \\
\text { thermal energy } \\
\text { storage in } \\
\text { concentrated } \\
\text { solar thermal } \\
\text { power plants: } \\
\text { A review } \\
\text { to recent } \\
\text { developments }\end{array}$ & $\begin{array}{l}\text { Ben Xu, Peiwen } \\
\text { Li, Cholik Chan }\end{array}$ & $\begin{array}{l}\text { The objective of this paper is to review the recent technolo- } \\
\text { gies of thermal energy storage (TES) using phase change } \\
\text { materials (PCM) for various applications, particularly con- } \\
\text { centrated solar thermal power (CSP) generation systems. Five } \\
\text { issues of the technology will be discussed based on a survey } \\
\text { to the state-of-the-art development and understandings. The } \\
\text { first part is about various phase change materials (PCM) in } \\
\text { thermal storage applications and recent development of PCM } \\
\text { encapsulation technologies. The second is the current status of } \\
\text { research and application of latent heat storage systems in CSP } \\
\text { plants. The third is the mathematical modeling and numerical } \\
\text { simulations to the phenomenon of latent heat thermal storage. } \\
\text { The fourth is about the issues of integration of a PCM-based } \\
\text { TES unit into a power generation system and the operation. } \\
\text { The last part is a discussion about the cost issues and com- } \\
\text { parison between sensible and latent heat TES systems. The } \\
\text { surveyed information will be very helpful to researchers and } \\
\text { engineers in energy storage industry and particularly solar } \\
\text { thermal power industry. }\end{array}$ & $\begin{array}{l}\text { Concentrated solar } \\
\text { power (CSP), } \\
\text { Thermal energy } \\
\text { storage (TES), } \\
\text { Phase change } \\
\text { material (PCM), } \\
\text { Latent heat }\end{array}$ & 2015 & 171 & [24] \\
\hline
\end{tabular}




\section{Conceptuales bases of the generation of electricity with solar thermal energy.}

a)

\section{Solar thermoelectric system with parabolic troughs.}

Thermal solar powered plants that use cylindricalparabolic cutters use a curved cylindrical mirror to reflect direct solar radiation on a glass tube containing a heat carrier fluid located along the cylinder, positioned at the focal point of these screens reflectors. The variations of the solar position during the day, is followed by tilting the cylinder from East to West, ensuring that the direct radiation remains focused on the sensor [16, 25]. The receiver conduit is enclosed in a glass chamber and vacuum. The fluid containing the captured thermal energy is transported to a thermal engine where approximately one third of this energy is transformed into electricity [26]. These systems, due to their thermal accumulation facilities, have the ability to operate with a certain autonomy, in the absence of sunlight. This process is detailed in figure 8 .

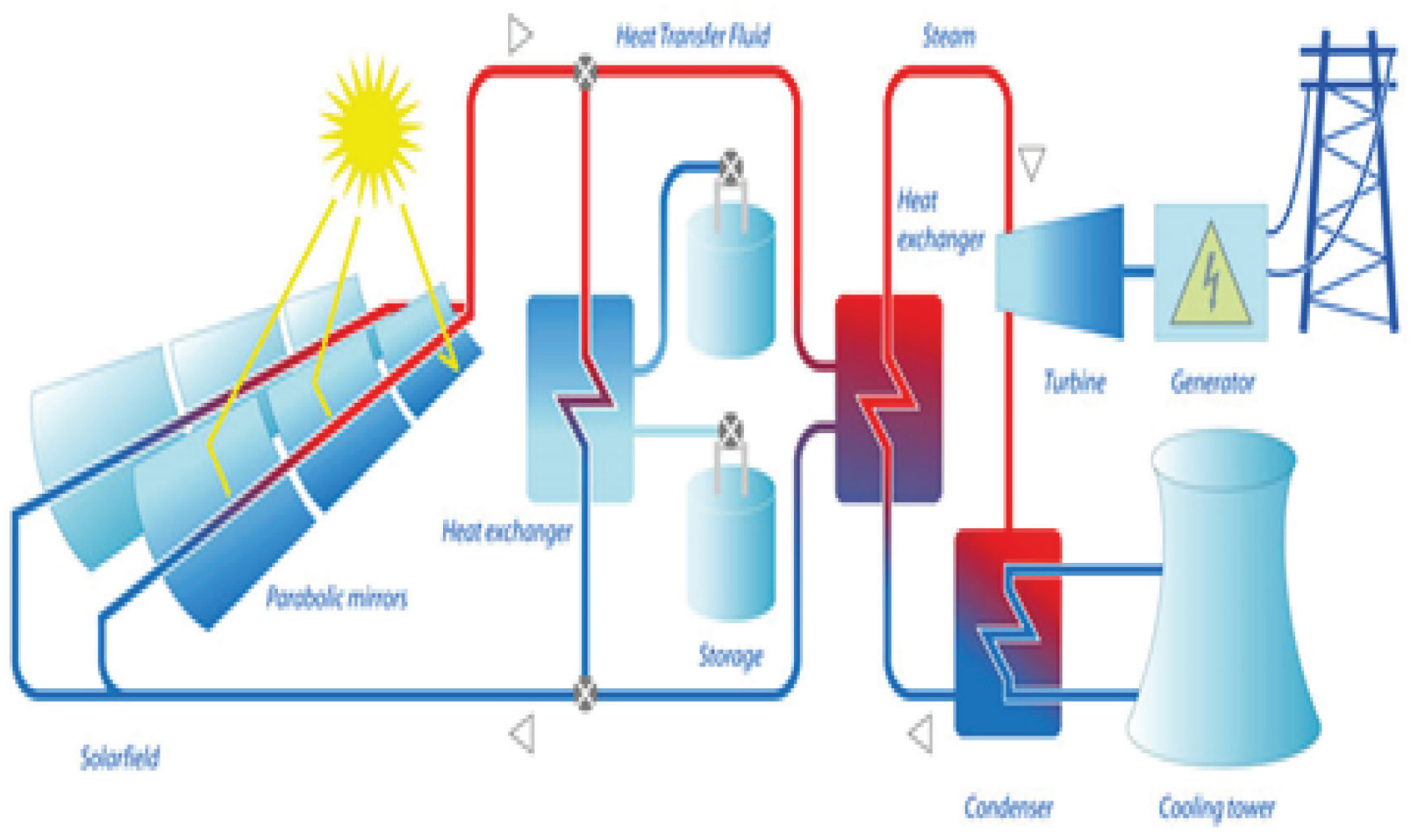

Figure 8. Thermoelectric system activated with solar energy from parabolic collectors.

\section{b)}

\section{Solar central tower thermoelectric system.}

A central tower solar installation, also known as a heliostat power plant, is a type of solar oven that uses a tower to receive concentrated sunlight. For this, it uses a group of flat, mobile mirrors called heliostats, which allow to focus the solar rays in a collector space located in the tower, this area is called the solar oven [27, 28]. Figure 9 illustrates the described process. The initial designs used these focused rays to heat water and used the resulting steam to drive a turbine. New designs have been obtained using liquid sodium and systems are now in operation that use molten salts as working fluids ( $40 \%$ potassium nitrate, $60 \%$ sodium nitrate). These working fluids have a high heat capacity, which can be used to store thermal energy. These heat carriers are responsible for supplying the necessary energy for the water to become the steam used to power the turbines. These designs also allow the generation of electrical energy even in the absence of solar radiation. 


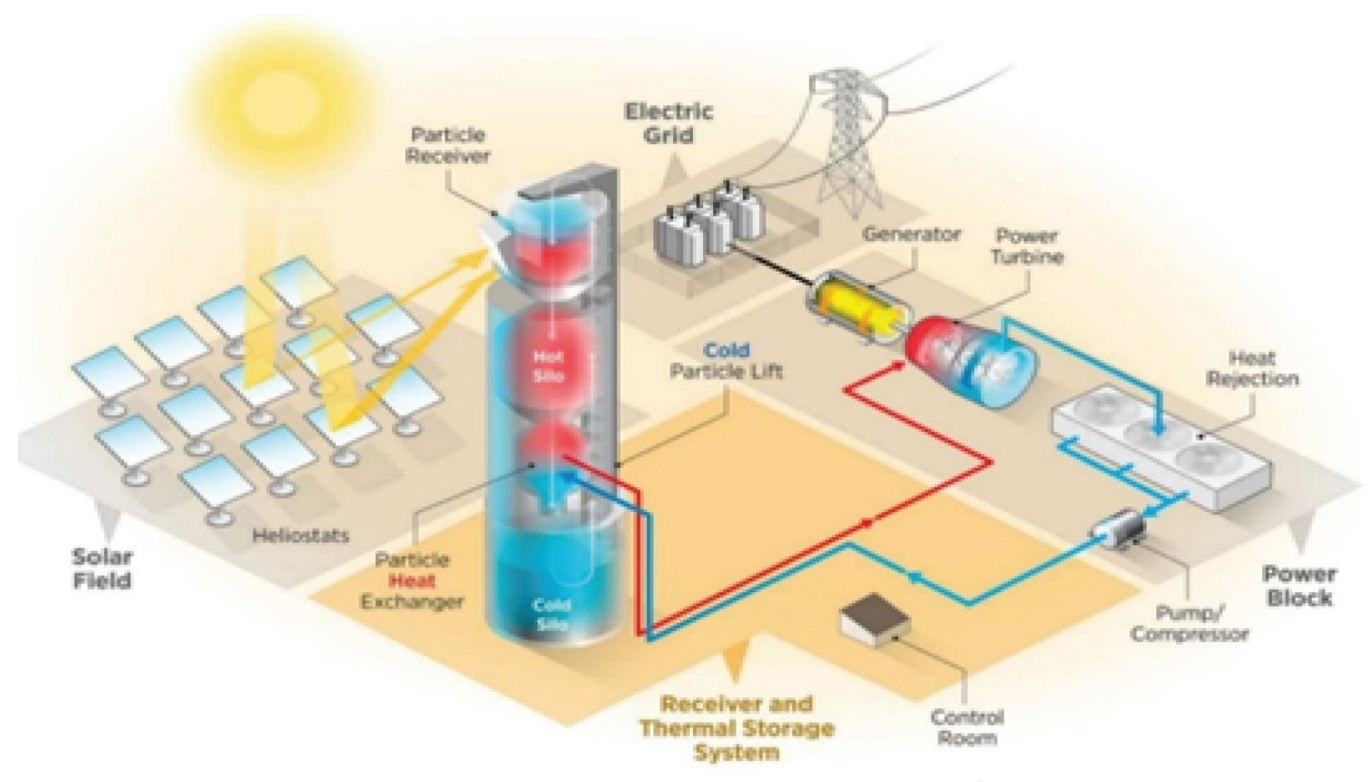

Figure 9. Thermoelectric system activated with energy from a solar concentration tower.

c)

\section{Solar chimneys.}

Solar chimneys represent a technology that combines solar thermal, wind and geothermal technology for electrical generation based on a phenomenon as simple as natural convection [29, 30]. The plant consists of a circular surface of land that is covered with a transparent material with a central hollow tower, the air when heated ascends by the chimney moving turbines that are inside [31-33]. A pipeline buried in the ground serves as thermal storage, guaranteeing operation 24 hours a day even without solar radiation. Figure 10 exemplifies this technology.

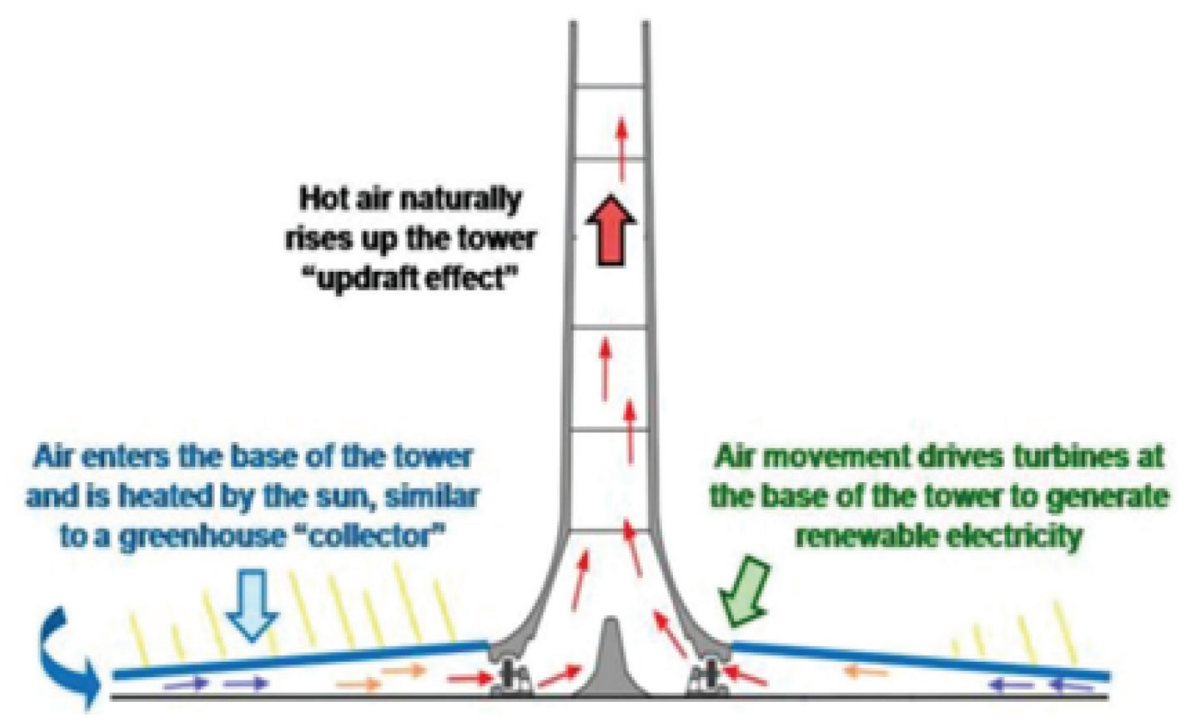

Figure 10. Solar tower or chimney.

Table 2 shows the most innovative research in recent years; for each of the techniques for generating electricity from solar thermal energy, discussed above. This criterion is the opinion of the authors of this article, and is based on techniques and materials proposed in these scientific contributions. 
Table 2. Most innovative contributions, for each of the techniques for generating electricity through solar thermal energy.

\begin{tabular}{|c|c|c|c|c|c|}
\hline Article title & Authors & Abstract & Keywords & Year & Reference \\
\hline $\begin{array}{l}\text { Multi-criteria } \\
\text { optimization of } \\
\text { an integrated } \\
\text { energy system with } \\
\text { thermoelectric } \\
\text { generator, parabolic } \\
\text { trough solar collector } \\
\text { and electrolysis for } \\
\text { hydrogen production }\end{array}$ & $\begin{array}{l}\text { Habibollahzade } \\
\text { A, Gholamian } \\
\text { E, Ahmadi P, } \\
\text { Behzadi A }\end{array}$ & $\begin{array}{l}\text { In this research paper, a newly energy system consisting of parabolic trough } \\
\text { solar collectors (PTSC) field, a thermoelectric generator (TEG), a Rankine cycle } \\
\text { and a proton exchange membrane (PEM) is proposed. The integration is per- } \\
\text { formed by establishing a TEG instead of the condenser as power generation } \\
\text { and cooling unit thereafter surplus power output of the TEG is transferred to the } \\
\text { PEM electrolyzer for hydrogen production. The integrated renewable energy } \\
\text { system is comprehensively modeled and influence of the effective parameters is } \\
\text { investigated on exergy and economic indicators through the parametric study to } \\
\text { better understand the system performance. Engineering equation solver (EES) } \\
\text { as a potential engineering tool is used to simulate the system and obtain the } \\
\text { desired results. In order to optimize the system, a developed multi-objective } \\
\text { genetic algorithm MATLAB code is applied to determine the optimum operating } \\
\text { conditions of the system. Obtained results demonstrate that at optimum working } \\
\text { condition from exergy viewpoint, exergy efficiency and total cost are } 12.76 \% \\
\text { and } 61.69 \$ / G J \text {, respectively. Multi-objective optimization results further show } \\
\text { that the final optimal point which is well-balanced between exergy efficiency } \\
\text { and total cost, has the maximum exergy efficiency of } 13.29 \% \text { and total cost of } \\
63.96 \$ / G J, \text { respectively. The corresponding values for exergy efficiency and } \\
\text { total cost are } 10.01 \% \text { and } 60.21 \$ / G J \text { for optimum working condition from eco- } \\
\text { nomic standpoint. Furthermore, hydrogen production at well-balanced operating } \\
\text { condition would be } 2.28 \mathrm{~kg} / \mathrm{h} \text {. Eventually, the results indicate that establishing } \\
\text { the TEG unit instead of the condenser is a promising method to optimize the } \\
\text { performance of the system and reduce total cost. }\end{array}$ & $\begin{array}{l}\text { Multi-objective } \\
\text { optimization, PEME, } \\
\text { PTSC, Solar collector, } \\
\text { TEG, Thermoelectric } \\
\text { generator }\end{array}$ & 2018 & [20] \\
\hline $\begin{array}{l}\text { Numerical Modeling } \\
\text { of a Two-tower Type } \\
\text { Fluidized Receiver for } \\
\text { High Temperature Solar } \\
\text { Concentration by a } \\
\text { Beam-down Reflector } \\
\text { System }\end{array}$ & $\begin{array}{l}\text { Matsubara, K. } \\
\text { Sakai, H. } \\
\text { Kazuma, Y. } \\
\text { Sakurai, A. } \\
\text { Kodama, T. } \\
\text { Gokon, N. } \\
\text { Cho, H. S. } \\
\text { Yoshida, K. }\end{array}$ & $\begin{array}{l}\text { This study describes the flow and thermal field ofatwo-tower fluidized receiver, } \\
\text { aimed tobeincorporated into a beam-down reflector system.Anexperimental } \\
\text { visualization and numerical simulation were made to accumulate phenomeno- } \\
\text { logical knowledge, in order to complete the design of ademonstration model. } \\
\text { Visualization of the cold particle bed with no irradiation revealed that global } \\
\text { circulation occurs between the two towers by the aeration with different line } \\
\text { velocities. The numerical simulation revealed that this global circulation enhan- } \\
\text { cesthe transport of sensible heat from the irradiated layer in the high pressure } \\
\text { tower to the low pressure tower.The global circulation in the two-tower fluidized } \\
\text { receiver has the potential to be extended foruse inathermal receiver and direct } \\
\text { storage system.Unexpectedly, local circulations occur on the high and low pres- } \\
\text { sure sides, and are stronger than the global circulation. These local circulations } \\
\text { contribute tothe thermal mixing in each tower.The bottom distributor onthe low } \\
\text { pressure side can cause an uprising flowwhichleadsto the local circulation. The } \\
\text { design of the distributor is suggested to be elaborated based on these finding }\end{array}$ & $\begin{array}{l}\text { Beam-down reflector system } \\
\text { Fluidized bed } \\
\text { Numerical simulation } \\
\text { Solar receiver } \\
\text { Computer simulation } \\
\text { Fluidization } \\
\text { Numerical models } \\
\text { Reflection } \\
\text { Solar energy } \\
\text { Towers } \\
\text { Cold particles } \\
\text { Global circulation } \\
\text { High temperature } \\
\text { Low pressures } \\
\text { Reflector system } \\
\text { Solar concentration } \\
\text { Thermal mixing } \\
\text { Fluidized beds }\end{array}$ & 2015 & [34] \\
\hline
\end{tabular}




\begin{tabular}{|c|c|c|c|c|c|}
\hline $\begin{array}{l}\text { Mathematical } \\
\text { evaluation of solar } \\
\text { chimney power plant } \\
\text { collector, integrated } \\
\text { with external heat } \\
\text { source for non- } \\
\text { interrupted power } \\
\text { generation }\end{array}$ & $\begin{array}{l}\text { Aurybi, M. A. } \\
\text { Gilani, S. I. } \\
\text { Al-Kayiem, H. } \\
\text { H. } \\
\text { Ismaeel, A. A. }\end{array}$ & $\begin{array}{l}\text { One of the largest challenges in the use of solar energy for power generation } \\
\text { is the interruption at night and during cloudy weather. This study proposed a } \\
\text { new technique of integrating the solar chimney power plant with an external } \\
\text { heat source. The integration can be achieved by installing "Thermal Enhancing } \\
\text { Channels" inside the collector region between the canopy and the ground to } \\
\text { enhance the kinetic energy of the air inside the collector, eventually allowing } \\
\text { the plant to operate at night. The thermo-fluid dynamics of the proposed hybrid } \\
\text { system were modeled mathematically to evaluate the performance of the pro- } \\
\text { posed model. The analysis gave a good propaedeutic overview of solar chimney } \\
\text { power plant integrated with an external heat source. The results showed that the } \\
\text { temperature of the air inside the collector could be increased by the addition } \\
\text { of thermal enhancing channels within the collector of the solar chimney. The } \\
\text { increasing percentage of the temperature for the air inside the collector reached } \\
\text { to } 5.88 \% \text { and for power generation } 23.1 \% \text { when the wall temperature of thermal } \\
\text { enhancing channels is } 100^{\circ} \mathrm{C} \text { and solar intensity } 1000 \mathrm{~W} / \mathrm{m}^{2} \text {. }\end{array}$ & $\begin{array}{l}\text { Energy recovery } \\
\text { Hybrid energy system } \\
\text { Integrated solar collector } \\
\text { Solar chimney power } \\
\text { plant } \\
\text { Thermal enhancement } \\
\text { channels } \\
\text { Chimneys } \\
\text { Hybrid systems } \\
\text { Integration } \\
\text { Kinetic energy } \\
\text { Kinetics } \\
\text { Solar energy } \\
\text { Integrated solar collectors } \\
\text { Thermal enhancement } \\
\text { Solar chimneys }\end{array}$ & 2018 & [35] \\
\hline
\end{tabular}


The Solar Thermal Electricity (STE) plants that are currently in operation and under construction have been revised. The details of its solar collector configuration, solar field operating conditions, Thermal Energy Storage TES systems and cooling methods are summarized in Table 3 for the two most mature technologies, parabolic solar concentrators and solar concentration towers.

Table 3. Properties of thermal energy storage technologies (TES) in power plants with parabolic solar concentrators or solar concentration towers. Current technologies and trends [36, 37].

\begin{tabular}{|c|c|c|}
\hline Properties or characteristics & Parabolic solar concentrators & Solar concentration towers \\
\hline \multicolumn{3}{|l|}{ Technological maturity } \\
\hline \multicolumn{3}{|l|}{ Key technology providers } \\
\hline $\begin{array}{l}\text { Operating temperature of solar field } \\
\left({ }^{\circ} \mathrm{K}\right)\end{array}$ & $563-663$ & $563-838$ \\
\hline Typical plant capacity (KWe) & 100000 & $50000-100000$ \\
\hline Power block cycle & Superheated steam Rankine & $\begin{array}{c}\text { Saturated steam Rankine } \\
\text { Superheated steam Rankine }\end{array}$ \\
\hline Collector concentration (suns) & $70-80$ & $>1000$ \\
\hline Plant peak efficiency $(\%)$ & $14-20$ & $23-35$ \\
\hline $\begin{array}{l}\text { Annual average conversion efficiency } \\
(\%)\end{array}$ & $13-15$ & $14-18$ \\
\hline Power block fluid conditions & steam $653{ }^{\circ} \mathrm{K} / 10 \mathrm{MPa}$ & steam $813^{\circ} \mathrm{K} / 10 \mathrm{MPa}-16 \mathrm{MPa}$ \\
\hline Power cycle efficiency $(\%)$ & 37.7 & 41.6 \\
\hline Heat transfer fluid & $\begin{array}{c}\text { Synthetic oil, wáter / Direct Steam } \\
\text { Generation (DSG), molten salt } \\
\text { (demo), air } \\
\text { (demo) }\end{array}$ & $\begin{array}{c}\text { Water/steam (DSG), molten salt, air } \\
\text { (demo) }\end{array}$ \\
\hline Annual capacity factor $(\%)$ & $\begin{array}{l}\text { 20-25 without TES } \\
40-53 \text { with } 6 \text { h TES }\end{array}$ & $\begin{array}{l}40-45 \text { with } 6-7.5 \text { h TES } \\
65-80 \text { with } 12-15 \text { h TES }\end{array}$ \\
\hline Storage temperature range $\left({ }^{\circ} \mathrm{K}\right)$ & $566-666$ & $\begin{array}{l}\text { 563-838 for Molten Salt storage } \\
\text { 393-603 for Steam Accumulators }\end{array}$ \\
\hline Cooling method & Wet & Wet, dry \\
\hline Suitable for air cooling & Low to good & Good \\
\hline Water requirement $\left(\mathrm{m}^{3} / \mathrm{MWh}\right)$ & $\begin{array}{c}3 \text { (wet cooling) } \\
0.4-1.7 \text { (hybrid cooling) } \\
0.3 \text { (dry cooling) }\end{array}$ & $\begin{array}{c}1.8-2.8 \text { (wet cooling) } \\
0.3-1 \text { (hybrid cooling) } \\
0.3 \text { (dry cooling) }\end{array}$ \\
\hline $\begin{array}{l}\text { Cost capital (US \$ } / \mathrm{kW} \text { ) established } \\
\text { by Organization of Economic Co- } \\
\text { operation and Development (OECD) }\end{array}$ & $\begin{array}{c}\text { 4700-7300 (without TES) } \\
3100-4050 \text { (without TES, non- } \\
\text { OECD countries) } \\
\text { 6400-10700 (with TES) }\end{array}$ & 6400-10700 (with TES) \\
\hline
\end{tabular}

\section{DISCUSSION}

\section{Technological trends}

a) Thermal storage facilities.

The accumulation or thermal storage facilities allow to have energy in the absence of sunlight. This fact attenuates the difficulty represented by the intermittency in the incidence of the astro king in our world [38]. Thermal accumulation technology also helps to smooth fluctuations in energy demand during different periods of the day [39].

The trend in the use of storage material or thermal accumulation has been the molten salt. This is mainly suitable for generation with Rankine cycles. An interesting new option that is experienced is the ionic liquids, which are liquid 
salts at low temperature, but which can be used as a heat transfer fluid up to $400{ }^{\circ} \mathrm{C}$. These could possibly replace the molten salt in the future and provide an excellent non-flammable option for heat transfer and accumulation [40].

However, thermal storage in solid materials such as alumina, concrete or rock is increasingly popular in air heat transfer systems using volumetric receivers and may be considered in the future for use with Brayton or Stirling cycle turbines [41, 42].

\section{b) Electrical conversión.}

Rankine cycle motors seem to be the best option for plants that operate with parabolic solar collectors due to temperature conditions, on the other hand, the micro-turbines of the Brayton cycle are replacing Stirling engines in the market for this type of installation, with solar capture systems by tracking two axes; this fact leads to a significant reduction in costs $[43,44]$.

Organic low-temperature Rankine cycle engines operating with vacuum and parabolic tube collectors may be feasible as replacement options for photovoltaic panels in the future. Currently these are more expensive than photovoltaic systems due to the high cost of the engine; as motor costs fall with the increase in production, this could change [45].

Australian researchers are developing beam splitter technology to produce hybrid photovoltaic / thermal systems with very high global efficiency [46].

\section{c) Reflector.}

Most advanced systems now use a thin, mechanically thin glass $(<1 \mathrm{~mm})$ backed with silver. Aluminum is currently used in the production of vacuum tubes. It is expected that this practice will be generalized mainly in collectors working at low temperatures [47].

\section{d) Configuration.}

There is a trend towards an increasing trend towards Fresnel single-axle and two-axle systems. These allow lower structural costs, fixed receivers and a relatively easy reflector cleaning [48, 49].

\section{e) Propensions to a new market. Urban buildings.}

There is a growing acceptance for small modular systems, which can be installed in Hurdian buildings. The highly compact Fresnel systems and those of multi-solar towers, can offer spatial and aesthetic advantages on the roof surfaces of the buildings in cities. These can be used as combined heat and electric power systems where the plant is located close to the energy service consumer. This practice has the additional benefit of the reduction of energy losses due to transportation, which are important in the case of large generating plants that are usually located on the outskirts of cities[50]. There is a growing acceptance for small modular systems, which can be installed in Hurdian buildings. The highly compact Fresnel systems and those of multi-solar towers, can offer spatial and aesthetic advantages on the roof surfaces of the buildings in cities. These can be used as combined heat and electric power systems where the plant is located close to the energy service consumer[51]. This practice has the additional benefit of the reduction of energy losses due to transportation, which are important in the case of large generating plants that are usually located on the outskirts of cities.

\section{Trends in the global energy market}

\section{a) Next five years.}

In the coming years there will be an inevitable impulse in the commercial activity of solar thermal electricity due to the many programs and strategies for the implementation of renewable energy sources. Gram porte of the world energy generation that today is based on the burning of hydrocarbons, you will see the solar thermal alternative as a serious competitor [26]. This alternative is an effective and efficient solution to the problems of energy availability, environmental pollution and geopolitical tensions that currently threaten existence itself.

As can be seen in figure 2, the countries at the head of these technological practices represent developed nations. In order to be able to socialize this technology in developing countries, the Global Environment Fund has resources, but the bureaucratic setbacks and dependence on the oil and gas market limit the fertile environmentally 
responsible energy market in these nations. The equity and integrity of the incentives for renewable energy technologies will provoke the desired increase in solar thermal activity [52].

\section{b) Next decades.}

In the next 50 years, the market for solar thermal electricity must increase drastically to meet the growing energy demand and achieve today's necessary ecological energy management. Solar thermal generation has the least restrictions on the basis of resources that are requested to satisfy the expected generation requirements. In the works of D. Mills and RE Aguilar [53, 54] it is stated that the growth rates of generation with solar energy must exceed $25 \%$ per year during the next three decades so that the solar thermal electric generation reaches a dominant position in the market in the year 2050. To access the energy market in an impressive way, it will be necessary to install a thermal accumulation system coupled to these avocados, which will guarantee the stability of the electro-energy delivery to the grid.

Limitations of the investigation: The work is limited to reviews of articles contained in the Scopues directory. Only in English language. $75.9 \%$ of the contributions related in this work, are in the 2016-2018 period.

\section{CONCLUSIONS}

The energy crisis facing the planet and the political tensions that stem from it, evidence the need to focus on energy strategies that allow for independence and availability. Solar energy is a source of clean energy, free from the pressures of the political-economic environment and abundant in the most populated areas of the planet.

Scientists and researchers have made great progress in terms of efficiency and economic feasibility in the processes of generating electricity in thermo-solar installations. The great advantages of distributed generation and on-site generation, which this practice provides, in terms of quality of the energy service, is undeniable. We are facing a new industrial revolution, an opportunity to preserve the environment of our existence which is finite and vulnerable. Researchers in the countries of the world economic axis see this energy practice as a viable alternative. On the other hand, the thermal accumulation facilities allow to have energy in the absence of sunlight. This technique also allows smoothing fluctuations in energy demand during different periods of the day, increasing the competitiveness of solar thermal electricity systems.

\section{BIBLIOGRAPHIC REFERENCES}

[1] Q. Li, A. Shirazi, C. Zheng, G. Rosengarten, J. A. Scott, and R. A. Taylor, "Energy concentration limits in solar thermal heating applications," (in English), Energy, Article vol. 96, pp. 253-267, 2016.

[2] J. Mahmoudimehr and L. Loghmani, “Optimal management of a solar power plant equipped with a thermal energy storage system by using dynamic programming method," (in English), Proceedings of the Institution of Mechanical Engineers, Part A: Journal of Power and Energy, Article vol. 230, no. 2, pp. 219-233, 2016.

[3] S. Mihoub, A. Chermiti, and H. Beltagy, "Methodology of determining the optimum performances of future concentrating solar thermal power plants in Algeria," (in English), Energy, Article vol. 122, pp. 801810, 2017.

[4] M. Labordena, A. Patt, M. Bazilian, M. Howells, and J. Lilliestam, "Impact of political and economical barriers for concentrating solar power in Sub-Saharan Africa," (in English), Energy Policy, Article vol. 102, pp. 52-72, 2017.

[5] C. Prieto et al., "Effect of the impurity magnesium nitrate in the thermal decomposition of the solar salt," (in English), Solar Energy, Article in Press 2018.

[6] D. Mills, "Advances in solar thermal electricity technology," Solar energy, vol. 76, no. 1, pp. 19-31, 2004.

[7] K. K. D. Repole and S. M. Jeter, "Design and analysis of a high temperature particulate hoist for proposed particle heating concentrator solar power systems," 2016, vol. 1: American Society of Mechanical Engineers.

[8] A. A. Navarro, L. Ramírez, P. Domínguez, M. Blanco, J. Polo, and E. Zarza, "Review and validation of Solar Thermal Electricity 
potential methodologies," (in English), Energy Conversion and Management, Article vol. 126, pp. 42-50, 2016.

[9] C. Ortiz, M. C. Romano, J. M. Valverde, M. Binotti, and R. Chacartegui, "Process integration of Calcium-Looping thermochemical energy storage system in concentrating solar power plants," (in English), Energy, Article vol. 155, pp. 535-551, 2018.

[10] D. Bravo Hidalgo, "Energía y desarrollo sostenible en Cuba," Centro Azúcar, vol. 42, pp. 14-25, 2015.

[11] T. Markvart, Solar electricity. John Wiley \& Sons, 2000.

[12] W. Ding, A. Bonk, J. Gussone, and T. Bauer, "Electrochemical measurement of corrosive impurities in molten chlorides for thermal energy storage," (in English), Journal of Energy Storage, Article vol. 15, pp. 408-414, 2018.

[13] R. Cañedo Andalia, R. Rodríguez Labrada, and M. Montejo Castells, "Scopus: la mayor base de datos de literatura científica arbitrada al alcance de los países subdesarrollados," Acimed, vol. 21, no. 3, pp. 270-282, 2010.

[14] A.-W. Harzing, The publish or perish book. Tarma Software Research, 2011.

[15] B. J. Alqahtani and D. Patiño-Echeverri, "Integrated Solar Combined Cycle Power Plants: Paving the way for thermal solar," (in English), Applied Energy, Article vol. 169, pp. 927-936, 2016.

[16] C. Prieto, A. Rodríguez, D. Patiño, and L. F. Cabeza, "Thermal energy storage evaluation in direct steam generation solar plants," (in English), Solar Energy, Article vol. 159, pp. 501-509, 2018.

[17] G. Peiró, C. Prieto, J. Gasia, A. Jové, L. Miró, and L. F. Cabeza, "Two-tank molten salts thermal energy storage system for solar power plants at pilot plant scale: Lessons learnt and recommendations for its design, start-up and operation," (in English), Renewable Energy, Article vol. 121, pp. 236248, 2018.

[18] L. André and S. Abanades, "Evaluation and performances comparison of calcium, strontium and barium carbonates during calcination/carbonation reactions for solar thermochemical energy storage," (in English), Journal of Energy Storage, Article vol. 13, pp. 193-205, 2017.

[19] D. B. Hidalgo, "Una Revisión sobre Materiales para Almacenamiento de Energía Solar Térmica," Ingeniería, vol. 23, no. 2 , pp. 144-165, 2018.

[20] A. Habibollahzade, E. Gholamian, P. Ahmadi, and A. Behzadi, "Multi-criteria optimization of an integrated energy system with thermoelectric generator, parabolic trough solar collector and electrolysis for hydrogen production," (in English), International Journal of Hydrogen Energy, Article vol. 43, no. 31, pp. 14140-14157, 2018.

[21] Z. Li and Z. G. Wu, "Analysis of HTFs, PCMs and fins effects on the thermal performance of shell-tube thermal energy storage units," Solar Energy, Article vol. 122, pp. 382-395, 2015.

[22] S. S. M. Tehrani, R. A. Taylor, P. Saberi, and G. Diarce, "Design and feasibility of high temperature shell and tube latent heat thermal energy storage system for solar thermal power plants," Renewable Energy, Article vol. 96, pp. 120-136, 2016.

[23] E. Carrizosa, C. Domínguez-Bravo, E. Fernández-Cara, and M. Quero, "Optimization of multiple receivers solar power tower systems," Energy, Article vol. 90, pp. 2085-2093, 2015.

[24] B. Xu, P. Li, and C. Chan, "Application of phase change materials for thermal energy storage in concentrated solar thermal power plants: A review to recent developments," (in English), Applied Energy, Review vol. 160, pp. 286-307, 2015.

[25] C. Sharma, A. K. Sharma, S. C. Mullick, and T. C. Kandpal, "A study of the effect of design parameters on the performance of linear solar concentrator based thermal power plants in India," (in English), Renewable Energy, Article vol. 87, pp. 666-675, 2016.

[26] L. Zhu, Y. Zhu, D. Gu, H. Wu, and B. Wang, "Solar STEP coal conversion: Fully solardriven thermo- and electrochemical process for efficient transformation of coal to light 
fuel plus hydrogen," (in English), Applied Catalysis B: Environmental, Article vol. 209, pp. 372-382, 2017.

[27] B. M. Ziapour, M. Saadat, V. Palideh, and S. Afzal, "Power generation enhancement in a salinity-gradient solar pond power plant using thermoelectric generator," (in English), Energy Conversion and Management, Article vol. 136, pp. 283-293, 2017.

[28] Y. Grosu, O. Bondarchuk, and A. Faik, "The effect of humidity, impurities and initial state on the corrosion of carbon and stainless steels in molten HitecXL salt for CSP application," (in English), Solar Energy Materials and Solar Cells, Article vol. 174, pp. 34-41, 2018.

[29] S. Kiwan, M. Al-Nimr, and Q. I. Abdel Salam, "Solar chimney power-water distillation plant (SCPWDP)," (in English), Desalination, Article vol. 445, pp. 105-114, 2018.

[30] S. Jamali, M. Yari, and S. M. S. Mahmoudi, "Enhanced power generation through cooling a semi-transparent PV power plant with a solar chimney," (in English), Energy Conversion and Management, Article vol. 175, pp. 227-235, 2018.

[31] P. Zou, Q. Chen, Y. Yu, Q. Xia, and C. Kang, "Electricity markets evolution with the changing generation mix: An empirical analysis based on China 2050 High Renewable Energy Penetration Roadmap," (in English), Applied Energy, Article vol. 185, pp. 56-67, 2017.

[32] R. Rabehi, A. Chaker, T. Ming, and T. Gong, "Numerical simulation of solar chimney power plant adopting the fan model," (in English), Renewable Energy, Article vol. 126, pp. 1093-1101, 2018.

[33] S. Lal and S. C. Kaushik, "CFD simulation studies on integrated approach of solar chimney and borehole heat exchanger for building space conditioning," (in English), Periodica Polytechnica Mechanical Engineering, Article vol. 62, no. 4, pp. 255-260, 2018.

[34] K. Matsubara et al., "Numerical Modeling of a Two-tower Type Fluidized Receiver for High Temperature Solar Concentration by a Beam-down Reflector System,” 2015, vol. 69, pp. 487-496: Elsevier Ltd.

[35] M. A. Aurybi, S. I. Gilani, H. H. Al-Kayiem, and A. A. Ismaeel, "Mathematical evaluation of solar chimney power plant collector, integrated with external heat source for non-interrupted power generation," (in English), Sustainable Energy Technologies and Assessments, Article vol. 30, pp. 59-67, 2018.

[36] S. Kuravi, J. Trahan, D. Y. Goswami, M. M. Rahman, and E. K. Stefanakos, "Thermal energy storage technologies and systems for concentrating solar power plants," Progress in Energy and Combustion Science, vol. 39, no. 4, pp. 285-319, 2013/08/01/ 2013.

[37] P. Viebahn, Y. Lechon, and F. Trieb, "The potential role of concentrated solar power (CSP) in Africa and Europe-A dynamic assessment of technology development, cost development and life cycle inventories until 2050," Energy Policy, vol. 39, no. 8, pp. 4420-4430, 2011/08/01/2011.

[38] T. L. Ruwa, H. H. Adun, and S. Abbasoglu, "Thermal Energy storage for solar power plant applications," in 13th HONET-ICT International Symposium on Smart MicroGrids for Sustainable Energy Sources Enabled by Photonics and IoT Sensors, HONET-ICT 2016, 2016, pp. 170-174.

[39] W. Su, J. Darkwa, and G. Kokogiannakis, "Development of microencapsulated phase change material for solar thermal energy storage," Applied Thermal Engineering, Article vol. 112, pp. 1205-1212, 2017.

[40] E. González-Roubaud, D. Pérez-Osorio, and C. Prieto, "Review of commercial thermal energy storage in concentrated solar power plants: Steam vs. molten salts," (in English), Renewable and Sustainable Energy Reviews, Review vol. 80, pp. 133148, 2017.

[41] A. Fallahi, G. Guldentops, M. Tao, S. Granados-Focil, and S. Van Dessel, "Review on solid-solid phase change materials for thermal energy storage: Molecular structure and thermal properties," (in English), Applied Thermal Engineering, Review vol. 127, pp. 1427-1441, 2017. 
[42] R. Shi, D. Chandra, A. Mishra, A. Talekar, M. Tirumala, and D. J. Nelson, "Thermodynamic reassessment of the novel solid-state thermal energy storage materials: Ternary polyalcohol and amine system pentaglycerine-tris(hydroxymethyl)-amino-methaneneopentylglycol (PG-TRIS-NPG)," (in English), Calphad: Computer Coupling of Phase Diagrams and Thermochemistry, Article vol. 59, pp. 61-75, 2017.

[43] A. S. Wardhana, H. Suryoatmojo, and M. Ashari, "Design of parabolic solar concentrator to improve the optical efficiency for thermal engine generator using dual reflector Gregorian method," 2016, pp. 457464: Institute of Electrical and Electronics Engineers Inc.

[44] J. Wu, H. Hou, and Y. Yang, "The optimization of integration modes in solar aided power generation (SAPG) system," (in English), Energy Conversion and Management, Article vol. 126, pp. 774-789, 2016.

[45] E. Albizzati, "Evaluación de la sustentabilidad de instalaciones solares con colectores de placa plana y tubos evacuados," (in Spanish), Revista Internacional de Contaminacion Ambiental, Article vol. 32, no. 3, pp. 315-322, 2016.

[46] M. Abdelhamid et al., "Novel double-stage high-concentrated solar hybrid photovoltaic/ thermal (PV/T) collector with nonimaging optics and GaAs solar cells reflector," (in English), Applied Energy, Article vol. 182, pp. 68-79, 2016.

[47] P. Ungureşan, D. Petreuş, A. Pocola, and M. BĂlan, "Potential of Solar ORC and PV Systems to Provide Electricity under Romanian Climatic Conditions," 2016, vol. 85, pp. 584-593: Elsevier Ltd.
[48] C. K. Yang, T. C. Cheng, C. H. Cheng, C. C. Wang, and C. C. Lee, "Open-loop altitudeazimuth concentrated solar tracking system for solar-thermal applications," (in English), Solar Energy, Article vol. 147, pp. 52-60, 2017.

[49] W. Zhu, Y. Deng, and L. Cao, "Light-concentrated solar generator and sensor based on flexible thin-film thermoelectric device," (in English), Nano Energy, Article vol. 34, pp. 463-471, 2017.

[50] Y. Zhang, X. Bai, F. P. Mills, and J. C. V. Pezzey, "Rethinking the role of occupant behavior in building energy performance: A review," (in English), Energy and Buildings, Review vol. 172, pp. 279-294, 2018.

[51] R. Sekar, D. S. Suresh, and H. Naganagouda, "A review on power electronic converters suitable for renewable energy sources," in 2017 International Conference on Electrical, Electronics, Communication Computer Technologies and Optimization Techniques, ICEECCOT 2017, 2018, vol. 2018-January, pp. 501-506: Institute of Electrical and Electronics Engineers Inc.

[52] D. Bravo Hidalgo, "CLIMATIZACIÓN SOLAR DE EDIFICACIONES," Centro Azúcar, vol. 42, pp. 72-82, 2015.

[53] D. Mills, "Advances in solar thermal electricity technology," Solar Energy, vol. 76, no. 1-3, pp. 19-31, 1// 2004.

[54] R. E. Aguilar Alvarez et al., "Technical and economic feasibility of a solar-bio-powered waste utilization and treatment system in Central America," (in English), Journal of Environmental Management, Article vol. 184, pp. 371-379, 2016. 